\title{
Genus Peniophora from Chamba District in Himachal Pradesh
}

\author{
Poonam $^{1}$, Avneet Pal Singh $^{2 *}$ and Gurpaul Singh Dhingra ${ }^{2}$ \\ ${ }^{1}$ Government Post Graduate College, Chamba 176314, Himachal Pradesh, India \\ ${ }^{2}$ Department of Botany, Punjabi University, Patiala 147 002, Punjab, India \\ "Corresponding authorEmail: avneetbot@gmail.com \\ (Submitted on March 12, 2020; Accepted on May 10, 2020)
}

\begin{abstract}
The corticioid genus Peniophora Cooke (Agaricomycetes, Russulales, Peniophoraceae) is described from Chamba district (Himachal Pradesh) based on ten species. Peniophora lycii (Pers.) Höhn. \& Litsch. and P. rufomarginata (Pers.) Bourdot \& Galzin are described as new records for India and $P$. incarnata (Pers.) Cooke and $P$. violaceolivida (Sommerf.) Massee as new for Himachal Pradesh. In addition to these new records, $P$. limitata (Chaillet ex Fr.) Cooke and $P$. ovalispora Boidin, Lanq. \& Gilles are recorded as new to Chamba district. A key to the species of Peniophora from Chamba district is also presented.
\end{abstract}

Keywords: Basidiomycota, Agaricomycetes, Western Himalaya, wood rotting fungi.

\section{INTRODUCTION}

The genus Peniophora Cooke (Russulales, Peniophoraceae) is characteristic in having resupinate basidiocarps that are adnate, orbicular to confluent to effused with occasionally reflexed margins. The hymenophore is mostly smooth to tuberculate and often becomes cracked with age. The genus has monomitic hyphal system with simple-septate or clamped generative hyphae, clavate to subclavate, somewhat sinuous, 4-sterigmate basidia and allantoid to subcylindrical to ellipsoid to broadly ellipsoid or subglobose, smooth, thinwalled, inamyloid, acyanophilous basidiospores. Peniophora is represented by 121 known taxa worldwide (MycoBank, 2020 and Index Fungorum, 2020). The genus is mainly involved in the decay of lignin and cellulose and has been reported in association with both the living tree species as well as fallen wooden substrates.

So far, 18 species of the genus have been reported from India, with 7 from Himachal Pradesh and 4 from district Chamba. Ten species of the genus namely, Peniophora cinerea (Pers.) Cooke, P. incarnata (Pers.) Cooke, P. limitata (Chaillet ex Fr.) Cooke, P. lycii (Pers.) Höhn. \& Litsch., P. ovalispora Boidin, Lanq. \& Gilles, P. pithya (Pers.) J. Erikss., P. pseudoversicolor Boidin, $P$. rufomarginata (Pers.) Bourdot \& Galzin, P. suecica Litsch. and $P$. violaceolivida (Sommerf.) Massee, have been identified on the basis of macroscopic and microscopic features and comparison with authentic literature (Rehill and Bakshi, 1965; Rattan, 1977; Eriksson et al., 1981; Dhingra, 1993; Natarajan and Kolandavelu, 1998; Bhosle et al., 2005; Dhingra and Kaur, 2005; Andreasen and Hallenberg, 2009; Bernicchia and Gorjón, 2010; Dhingra et al., 2011; Ranadive et al., 2011; Sharma, 2012; Ranadive, 2013; Prashar and Ashok, 2013; Prashar and Lalita, 2013; Samita and Dhingra; 2013; Dhingra et al., 2014; Poonam et al., 2017; MycoBank, 2020). Peniophora lycii and $P$. rufomarginata are described as new records for India and $P$. incarnata and $P$. violaceolivida as new for Himachal Pradesh. In addition to these new records, $P$. limitata and $P$. ovalispora are recorded as new to Chamba district. A key to all 10 species has been provided. All specimens have been deposited at the Herbarium, Department of Botany, Punjabi University, Patiala (PUN). The colour citations are according to Kornerup and Wanscher(1978).

\section{Key to the species:}

1. Dendrohyphidia present ...................................... lycii

1. Dendrohyphidia absent ......................................... 2

2. Basidiospores broadly ellipsoid to subglobose ............ P. ovalispora

2. Basidiospores allantoid to suballantoid to subcylindrical to cylindrical to ellipsoid ............................................... 3

3. Basidiocarps very thin, subiculum poorly developed ..... .P. cinerea

3. Basidiocarps not as above, subiculum well developed ....4

4. Basidiocarps reddish orange to orange ........................5

4. Basidiocarps differently coloured ..............................6

5. Basal layer thin, less than $1 / 3$ rd of hymenium P. incarnata

5. Basal layer thick ............................ P. pseudoversicolor

6. Reflexed abhymenial side of the margins blackish brown ............................................... P. rufomarginata

6. Margins not of above type ........................................ 7

7. Gloeocystidia rounded to subcylindrical, frequent ..... P. violaceolivida

7. Gloeocystidia subfusiform or absent ........................8

8. Gloeocystidia absent, subiculum thick, dark ......... ..P. limitata

8. Gloeocystidia subfusiform ....................................... 9

9. Subiculum brown, dense.................................. pithya

9. Subiculum light brownish, loose .................... suecica

TAXONOMIC DESCRIPTIONS

1. Peniophora cinerea(Pers.) Cooke, Grevillea 8(45):20(1879).

- Corticium cinereum Pers., Neues Mag. Bot. 1: 111 (1794).

Figs. 1-7

Collections examined: India, Himachal Pradesh: Chamba, 


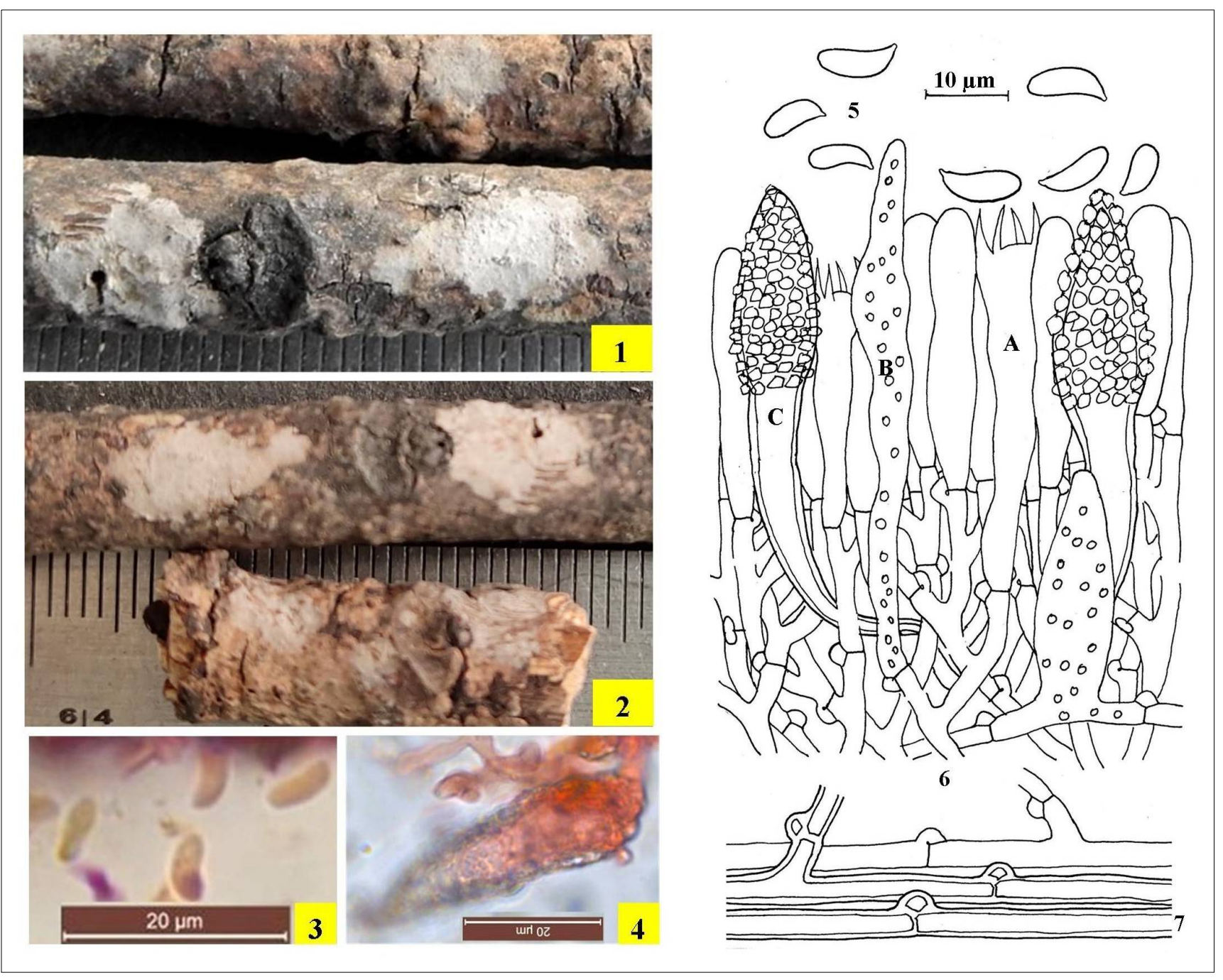

Figs. 1-7. Peniophira cinerea:1-2. Sporophore showing hymenial surface (1. Fresh, 2. Dry); 3-4. Photomicrographs (3. Basidiospores, 4. Metuloid) 5-7. Line diagrams showing 5. Basidiospores; 6 . Reconstruction showing a portion of hymenium and subhymenium (A. Basidium, B. Gloeocystidium, C. Metuloid) and 7.Generative hyphae.

Hardaspura, on sticks of Justicia adhatoda, Poonam 10475 (PUN), September 3, 2014; Udaipur, on sticks of J. adhatoda, Poonam 10476 (PUN), September 4, 2014; Dalhousie, Kalatop, on sticks of Pinus roxburghii, Poonam 10477 (PUN), September 3, 2014; Kihar, Churah, on sticks of Rhododendron macrophylla, Poonam 10478 (PUN), September 04, 2016.

Remarks: $P$. cinerea is characteristic in having resupinate basidiocarps with smooth to ganulose hymenophore, monomitic hyphal system with clamped generative hyphae, subfusiform gloeocystidia, conical metuloids, clavate to subclavate basidia and allantoid to suballantoid, thin-walled basidiospores. This species is described for the first time from tehsils Bharmour and Churah. Earlier it was reported from Uttarakhand (Rehil and Bakshi, 1965; Dhingra and Kaur, 2005), districts Chamba and Kullu of Himachal Pradesh and Jammu and Kashmir (Rattan, 1977), Maharashtra (Bhosle et al., 2005; Ranadive et al., 2011; Ranadive, 2013), and districts Chamba, Kullu and Sirmaur of Himachal Pradesh(Dhingra et al., 2014).
2. Peniophora incarnata (Pers.) P. Karst., Hedwigia 28:27 (1889).

- Thelephora incarnata Pers., Synopsis methodica fungorum: 573 (1801).

Figs. 8-16

Basidiocarp resupinate, effused, adnate, membranous, up to 280 $\mu \mathrm{m}$ thick in section; hymenial surface tuberculate, cracked both in fresh and dry states; orange white to pale orange when fresh, orange white on drying; margins thinning, paler concolorous. Hyphal system monomitic. Generative hyphae subhyaline, septate, clamped, smooth; horizontal, up to $5 \mu \mathrm{m}$ wide, less branched, thick-walled in the subicular zone; vertical, up to $3 \mu \mathrm{m}$ wide, richly branched, thin-walled in the subhymenial zone. Ancillary elements of 2 kinds: (i) Gloeocystidia subcylindrical, with basal clamp, $88-106 \times 6.6-7.2 \mu \mathrm{m}$, thin-walled, with oily contents stained in sulphovanillin; projecting up to $30 \mu \mathrm{m}$ out of the hymenium, thin-walled, (ii) Metuloids conical to subfusiform, with basal clamp, 60-74 $\times 8.5-12 \mu \mathrm{m}$, thick-walled, heavily encrusted; projecting up to $20 \mu \mathrm{m}$ out of the hymenium. Basidia 


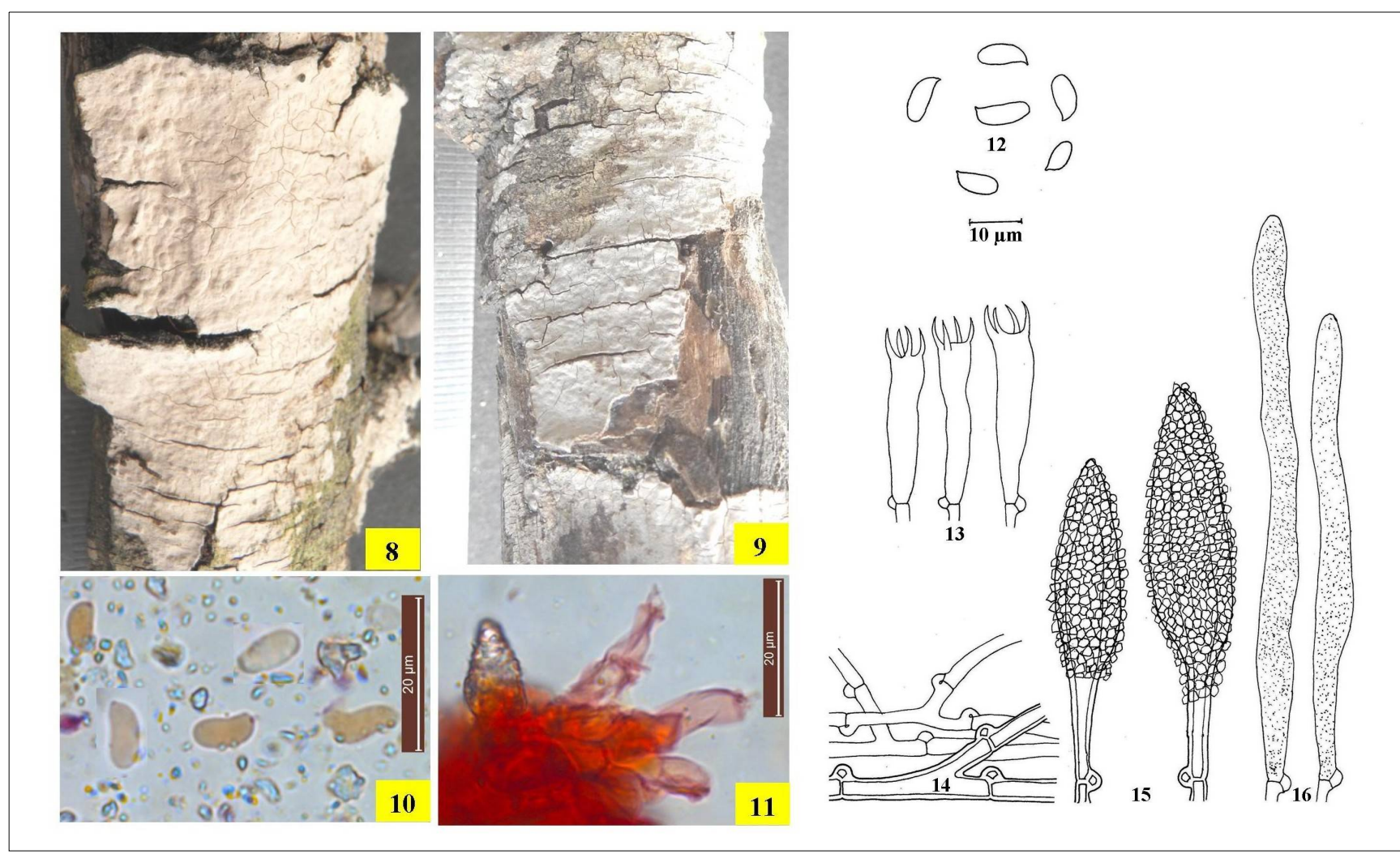

Figs. 8-16. Peniophora incarnata: 8-9 Sporophore showing hymenial surface (8. Fresh, 9. Dry); 10-11. Photomicrographs showing 10. Basidiospores, 11. Metuloid; 12-16. Line diagrams showing 12.Basidiospores; 13. Basidia, 14. Metuloids, 15. Gloeocystidia and 16.Generative hyphae.

clavate to subclavate, somewhat sinuous, $29-33 \times 6.1-6.7 \mu \mathrm{m}$, sterigmata up to $5.5 \mu \mathrm{m}$ long. Basidiospores $6.5-11 \times 3.4-4.6 \mu \mathrm{m}$, ellipsoid to subcylindrical to suballantoid, thin-walled, smooth, acyanophilous, inamyloid.

Collections examined: India, Himachal Pradesh: Chamba, Hardaspura, Aadarsh Nagar, on branch of Robinia pseudoacacia, Poonam 9181 (PUN), November 04, 2015; Hardaspura, on sticks of $R$. pseudoacacia, Poonam 10485 (PUN), November 04, 2015.

Remarks: $P$. incarnata is reported for the first time from the state of Himachal Pradesh. Earlier it was reported from India by Rehill and Bakshi (1965) from different parts of India and Natarajan and Kolendavelu (1998) from Tamil Nadu.

3. Peniophora limitata (Chaillet ex Fr.) Cooke, Grevillea, 8 (45): 21 (1879).

- Thelephora limitata Chaillet ex Fr., Elench. Fung. (Greifswald) 1: 222 (1828).

Figs. 17-21

Basidiocarp resupinate, effused, adnate, up to $280 \mu \mathrm{m}$ thick in section; hymenial surface smooth both in fresh and dry states; reddish white to pale red both in fresh and dry states; margins thinning, paler concolorous. Hyphal system monomitic. Generative hyphae septate, clamped, smooth; up to $4.1 \mu \mathrm{m}$ wide, light brown, thin- to thick-walled, less branched in the subicular zone; up to $3.2 \mu \mathrm{m}$ wide subhyaline, vertical, richly branched, thin-walled in the subhymenial zone. Ancillary elements initially appear as thin-walled cystidia with oily contents but later on appear as metuloids; metuloids conical to subfusiform, with basal clamp, 41-54 × 12-14.4 $\mu \mathrm{m}$, thickwalled, heavily encrusted; projecting up to $10 \mu \mathrm{m}$ out of the hymenium. Basidia subclavate, sinuous, 44-50 × 11-13 $\mu \mathrm{m}$; sterigmata up to $6.6 \mu \mathrm{m}$ long. Basidiospores $8.3-12 \times 3.2-4$ $\mu \mathrm{m}$, allantoid to suballantoid, thin-walled, smooth, acyanophilous, inamyloid.

Collection examined: India, Himachal Pradesh, Chamba, Udaipur, on sticks of Justicia adhatoda, Poonam 10471 (PUN), September 6, 2015.

Remarks: Peniophora limitata is a new addition to corticioid mycoflora of district Chamba. Previous reports from India are by Dhingra (1993) and Dhingra et al., (2011) from Eastern Himalaya.

\section{Peniophora lycii (Pers.) Höhn. \& Litsch., Sitzungsberichte der Kaiserlichen Akademie der Wissenschaften Math.- naturw. Klasse Abt. I116: 747 (1907).}

- Thelephora lycii Pers., Mycologia Europaea 1: 148 (1822).

Figs. 22-28

Basidiocarps resupinate, effused, adnate, up to $200 \mu \mathrm{m}$ thick in section; hymenial surface smooth both in fresh and dry states; yellowish grey to bluish grey when fresh, yellowish grey on drying; margins pruinose, paler concolorous. Hyphal system monomitic. Generative hyphae septate, clamped, smooth; light brown, thin- to thick-walled, horizontal, up to $3.1 \mu \mathrm{m}$ wide, less branched in the subicular zone; subhyaline, 


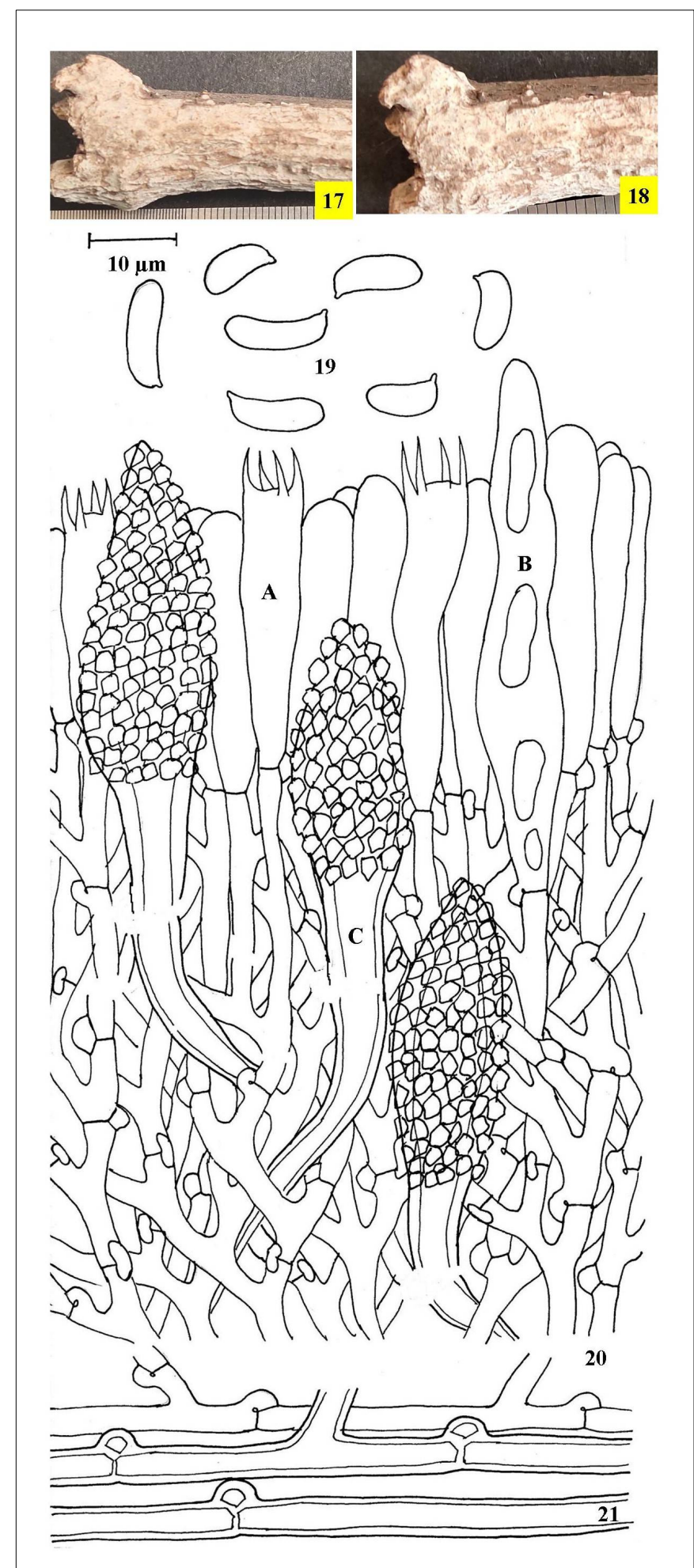

Figs. 17- 21. Peniophora limitata:17-18. Sporophore showing hymenial surface (17. Fresh, 18. Dry); 19-21. Line diagrams showing 19. Basidiospores; 20. Reconstruction showing a portion of hymenium and subhymenium (A. Basidium, B. Young cystidium, C. Metuloid) and 21.Generative hyphae.

vertical, up to $2.5 \mu \mathrm{m}$ wide, richly branched, thin-walled in the subhymenial zone. Ancillary elements of 3 kinds: (i)

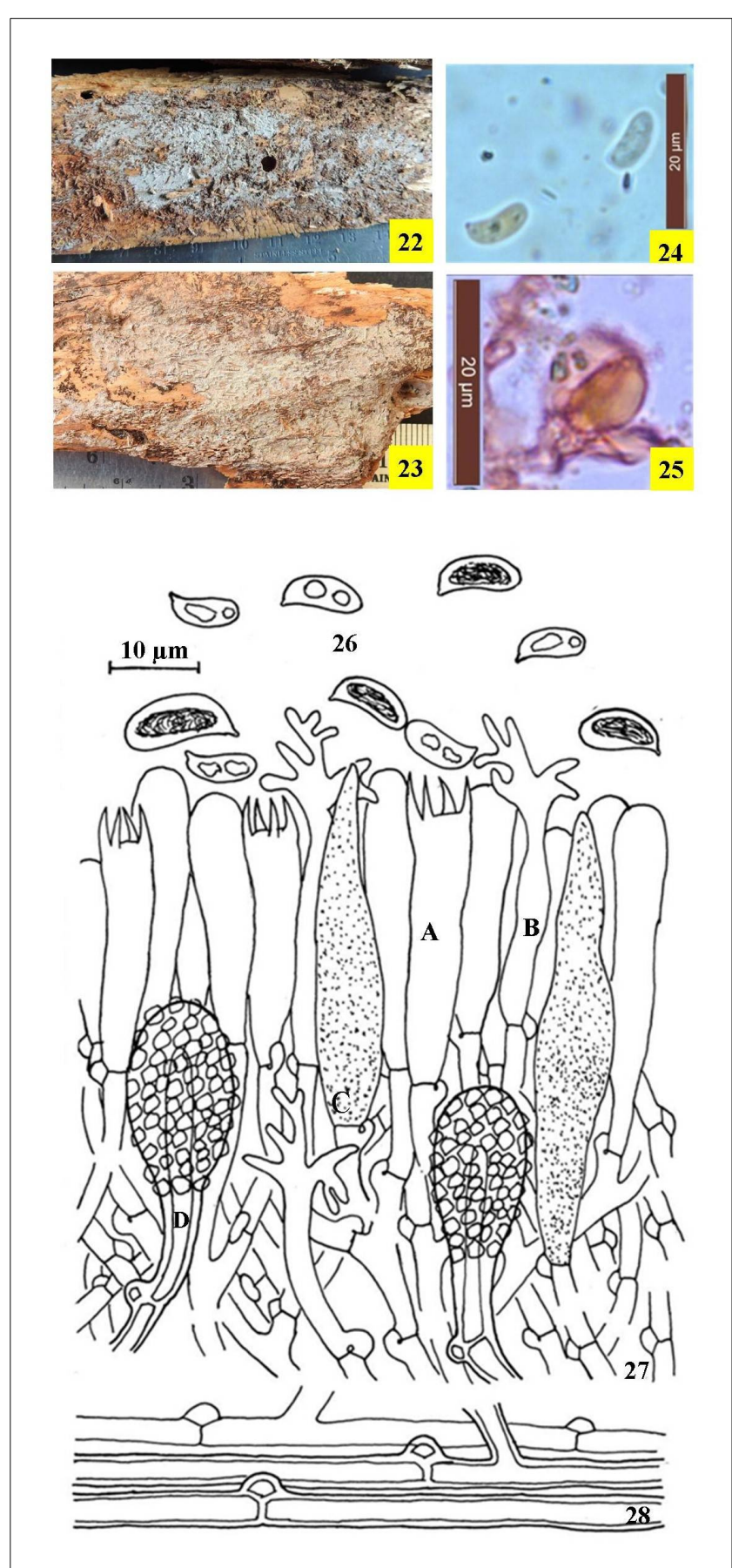

Figs. 22-28. Peniophora lycii: 22-23. Sporophore showing hymenial surface (22. Fresh, 23. Dry); 24-25. Photomicrographs showing 24. Basidiospores, 25. Metuloid; 26-28. Line diagrams showing 26.Basidiospores; 27. Reconstruction showing a portion of hymenium and subhymenium (A. Basidium, B. Dendrohyphidia, C. Gloeocystidium, D.Metuloid) and 28.Generative hyphae.

Gloeocystidia fusiform, with basal clamp, 39-53 × 7-8.8 $\mu \mathrm{m}$, thin-walled, with oily contents positive to sulphovanillin; embedded in the hymenium (ii) Metuloids obovate to oblong, with basal clamp, 24-29 × 9.2-11.6 $\mu \mathrm{m}$, thick-walled, with crystalline deposits; embedded in the hymenium (iii) 
Dendrohyphidia richly branched in the apical region, with basal clamp, 36-50 × 3.3-4.4 $\mu \mathrm{m}$, thin-walled. Basidia subclavate, sinuous, $21-32 \times 5-6.6 \mu \mathrm{m}$; sterigmata up to 5.5 $\mu \mathrm{m}$ long. Basidiospores 7.7-12.5 $\times 3.8-5.5 \mu \mathrm{m}$, allantoid to suballantoid, thin-walled, smooth, acyanophilous, inamyloid.

Collections examined: India, Himachal Pradesh, Chamba, Churah, Bhandal, on stump of Picea smithiana, Poonam 10102 (PUN), August 15, 2014; Churah, Bhandal, on stump of P. smithiana, Poonam 10741 (PUN), August 15, 2014.

Remarks: Peniophora lycii, a new report of corticioid fungi from India, is different from other species of the genus in having dedrohyphidia. Earlier, it has been reported from Belgium, Caucasus, Croatia, Estonia, France, Germany, Ireland, Italy, Poland, Portugal, Macedonia, Montenegro, Slovenia, Serbia, Spain and Ukrain (MycoBank, 2020).

5. Peniophora ovalispora Boidin, Lanq. \& Gilles, Bulletin de la Société Mycologique de France 107 (3): 108 (1991).

Figs. 29-37

Basidiocarps resupinate, effused, adnate, up to $240 \mu \mathrm{m}$ thick in section; hymenial surface smooth both in fresh and dry states; orange white to reddish white both in fresh and dry states; margins fibrilliose, paler concolorous. Hyphal system monomitic. Generative hyphae septate, clamped, smooth; horizontal, light brown, up to $4 \mu \mathrm{m}$ wide, less branched, thick-walled in the subicular zone; subhyaline, vertical, up to $3 \mu \mathrm{m}$ wide, richly branched, thin-walled in the subhymenial zone. Ancillary elements of 2 kinds: (i) Gloeocystidia subfusiform, with basal clamp, 46-60 × 5.5$6.1 \mu \mathrm{m}$, thin-walled, with oily contents negative to sulphovanillin; projecting $20 \mu \mathrm{m}$ out of the hymenium. (ii) Metuloids conical to subfusiform, with basal clamp, 44-56 $\times 7.8-13 \mu \mathrm{m}$, thick-walled, heavily encrusted; projecting up to $15 \mu \mathrm{m}$ out of the hymenium Basidia clavate to subclavate, somewhat sinuous, $21-26 \times 5-6.1 \mu \mathrm{m}$; sterigmata up to $5 \mu \mathrm{m}$ long. Basidiospores 5.5-7.2 × 3.2-5.5 $\mu \mathrm{m}$, broadly ellipsoid to subglobose, thin-walled, smooth, acyanophilous, inamyloid.

Collections examined: India, Himachal Pradesh: Chamba, Udaipur, Chikryani on sticks of Rosa moschata, Poonam 9182 (PUN), September 06, 2015; Udaipur, Chikryani on sticks of R. moschata, Poonam 10472 (PUN), September 06, 2015.

Remarks: P. ovalispora differs from other described species in having broadly ellipsoid to subglobose basidiospores. It is described for the first time from Chamba district.

6. Peniophora pithya (Pers.) J. Erikss., Fungi Exsiccati Suecici Fasc. 37-38: 37 (1950).

- Thelephora pithya Pers., Mycologia Europaea 1: 146 (1822).

Figs. 38-43

Collections examined: India, Himachal Pradesh: Chamba, Dalhousie, Jandrighat, on Cedrus deodara stump, 10473 Poonam (PUN), November 05, 2013; Pangi, Sural, on stick of Betula utilis, Poonam 10474 (PUN), September 13, 2016.

Remarks: $P$. pithya is distinguished from other species in having well-developed, dense subiculum and is described

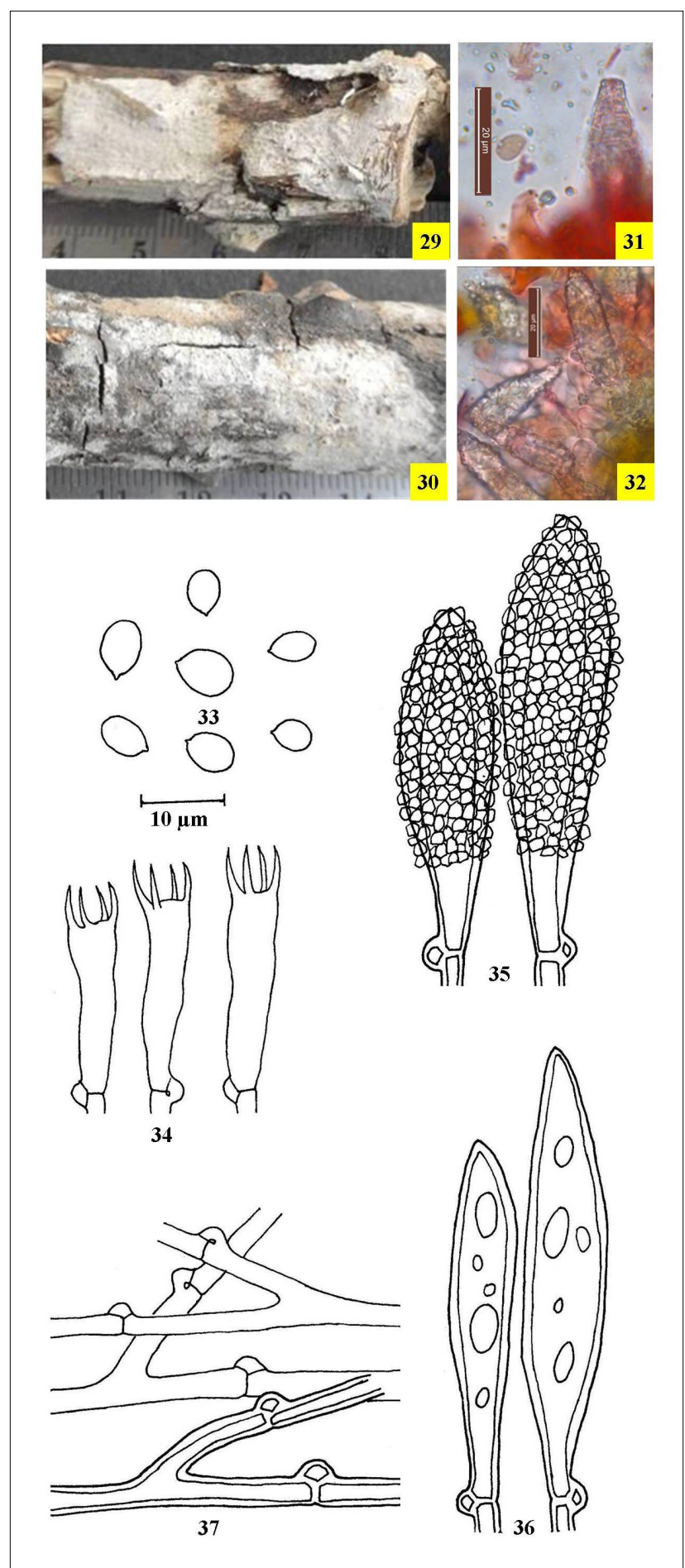

Figs. 29-37. Peniophora ovalispora: 29-30. Sporophore showing hymenial surface (29. Fresh, 30. Dry); 31-32. Photomicrographs showing 31. Basidiospores, 32. Metuloids; 33-37. Line diagrams showing 33. Basidiospores; 34. Basidia, 35. Metuloids, 36. Gloeocystidia and37.Generativehyphae.

for the first time from tehsil Pangi in the study area. Earlier it was reported from Eastern Himalaya by Dhingra (1993) and Dhingra et al., (2011); districts Chamba and Shimla of Himachal Pradesh by Dhingra et al., (2014) and 


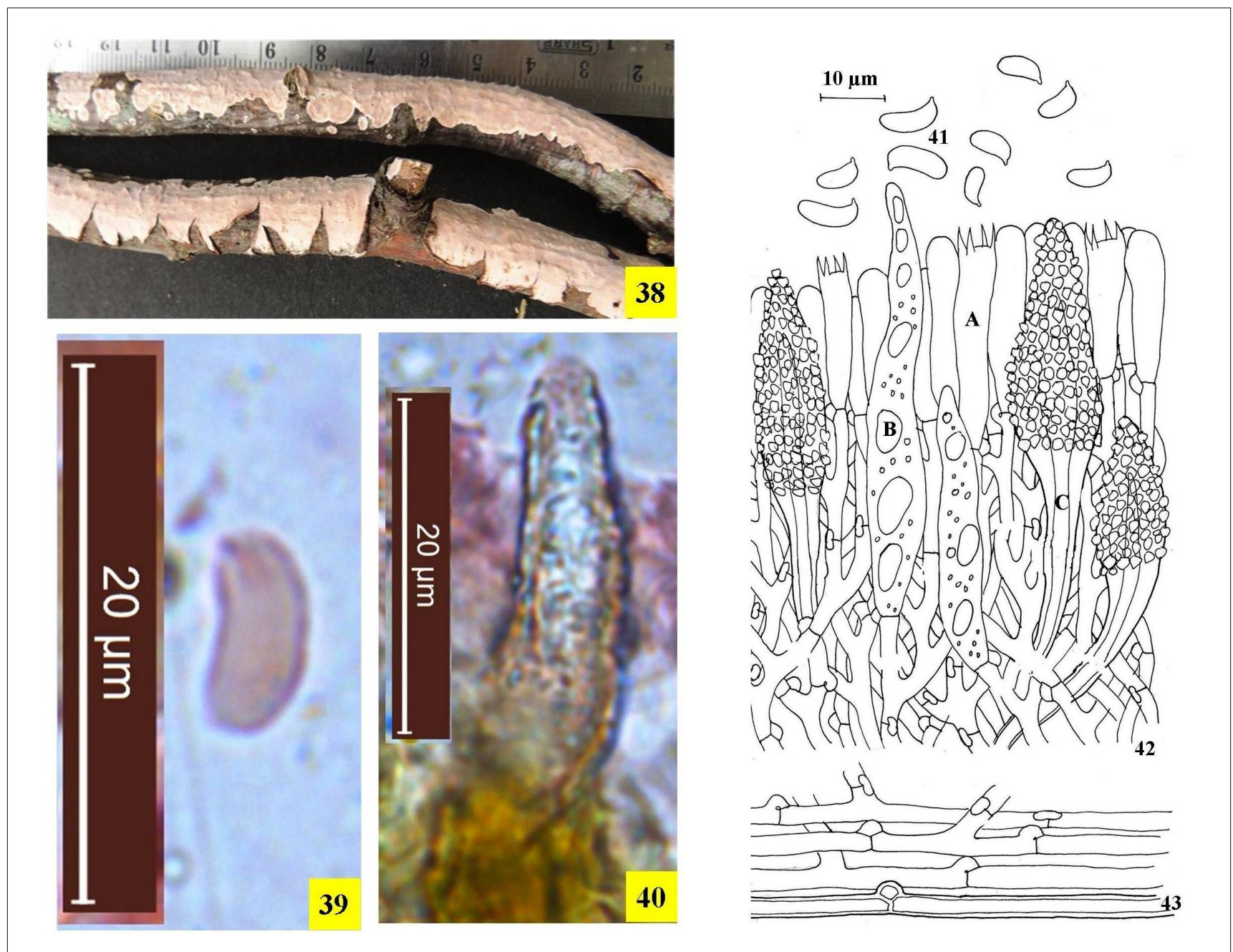

Figs. 38-43. Peniophora pithya: 38. Sporophore showing hymenial surface; 39-40. Photomicrographs showing 39. Basidiospore, 40. Metuloid; 41-43. Line diagrams showing 41. Basidiospores; 42. Reconstruction showing a portion of hymenium and subhymenium(A. Basidium, B. Gloeocystidium, C. Metuloid) and 43.Generative hyphae.

Maharashtra by Ranadive et al., (2011) and Ranadive (2013).

7. Peniophora pseudoversicolor Boidin, Bulletin Mensuel de la Société Linnéenne de Lyon 34: 162,(1965). Figs.44-51

Collections examined: India, Himachal Pradesh, Chamba, Udaipur, on sticks of Justicia adhatoda, Poonam 7648 (PUN), September 06, 2015; Udaipur, on sticks of $J$. adhatoda, Poonam 10479 (PUN), September 06, 2015; Udaipur, on sticks of J. adhatoda, Poonam 10480 (PUN), September 06, 2015; Udaipur, on sticks of $J$. adhatoda, Poonam 10481 (PUN), September 06, 2015; Udaipur, on burnt branch of Pyrus persica, Poonam 10482 (PUN), January $01,2018$.

Remarks: P. pseudoversicolor is typical in having reddish orange to brownish orange basidiocarps with well developed subiculum, vesicular to subcylindrical gloeocystidia with oily contents stained in sulphovanillin, conical metuloids and allantoid to suballantoid basidiospores. Poonam et al. (2017) described it for the first from India based on the specimen collected from district Chamba.
8. Peniophora rufomarginata (Pers.) Bourdot \& Galzin, Bulletin de la Société Mycologique de France 28 (4): 408 (1913).

\section{- Thelephora rufomarginata Pers., Mycologia Europaea} 1: 124(1822).

Figs.52-58

Basidiocarps resupinate, effused, adnate, occasionally reflexed at the margins, up to $400 \mu \mathrm{m}$ thick in section; hymenial surface smooth both in fresh and dry states; orange white to reddish white when fresh, orange white to grayish orange on drying; margins thinning, paler concolorous, somewhat abrupt or reflexed, underside brownish black. Hyphal system monomitic. Generative hyphae septate, clamped, smooth; light brown, horizontal, up to $4 \mu \mathrm{m}$ wide, less branched, thin-to thick-walled in the subicular zone; subhyaline, vertical, up to $3.3 \mu \mathrm{m}$ wide, richly branched, thinwalled in the subhymenial zone. Metuloids conical to subfusiform, with basal clamp, 54-61 × 9.4-13 $\mu \mathrm{m}$, thickwalled, heavily encrusted; projecting up to $20 \mu \mathrm{m}$ out of the hymenium. Basidia clavate, sinuous, 32-44 × 4.9-7.2 $\mu \mathrm{m}$; sterigmata up to $5 \mu \mathrm{m}$ long. Basidiospores $6.4-8.8 \times 2.5-3.3$ 


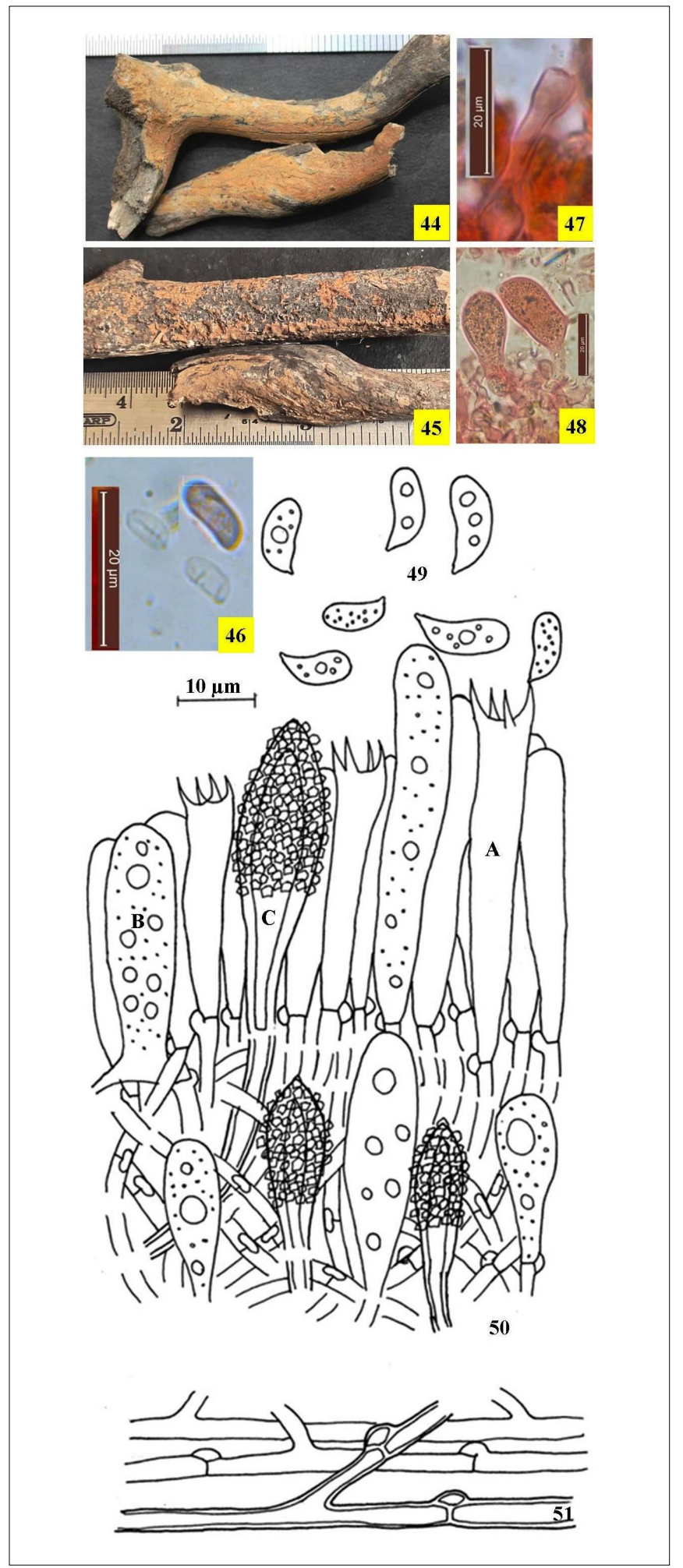

Figs. 44-51 Peniophora pseudoversicolor: Sporophore showing hymenial surface (44. Fresh, 45. Dry); 46-48. Photomicrographs showing 46. Basidiospores, 47. Basidium and 48. Gloeocystidia; 49-51. Line diagrams showing 49. Basidiospores; 50 . Reconstruction showing a portion of hymenium and subhymenium (A. Basidium, B. Gloeocystidium, C. Metuloid); 51.Generative hyphae.
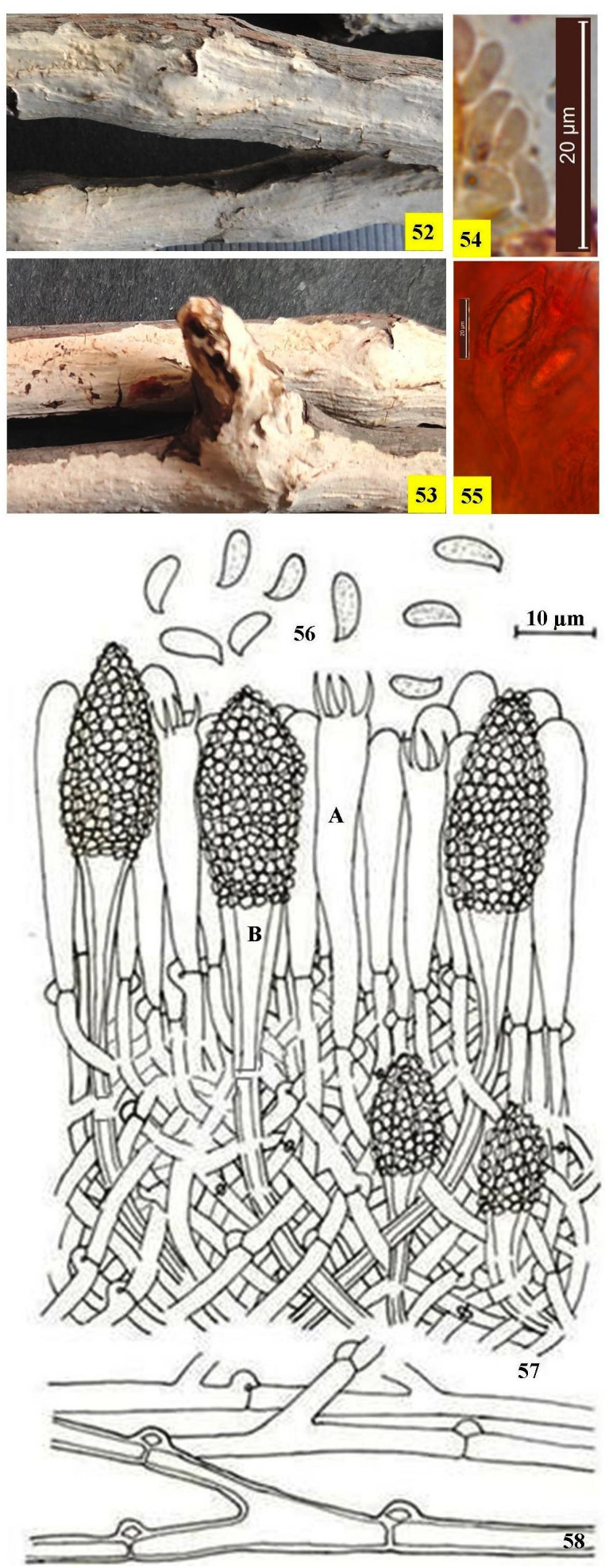

52-58. Peniophora rufomarginata: 52-53. Sporophore showing hymenial surface (52. Fresh, 53. Dry); 54-55. Photomicrographs showing 54. Basidiospores, 55. Metuloids; 56-58. Line diagrams showing 56. Basidiospores, 57. Reconstruction showing a portion of hymenium and subhymenium (A. Basidium, B. Metuloid); 58.Generative hyphae. 
$\mu \mathrm{m}$, allantoid to suballantoid, thin-walled, smooth, acyanophilous, inamyloid.

Collections examined: India, Himachal Pradesh: Chamba, Udaipur, Chikryani, on sticks of Justicia adhatoda, Poonam 9183 (PUN), July23, 2017; Udaipur, Chikryani, on sticks of $J$. adhatoda, Poonam 10739 (PUN), July 23, 2017; Udaipur, Chikryani, on sticks of $J$. adhatoda, Poonam 10740 (PUN), July 23, 2017.

Remarks: P. rufomarginata is being described for the first time from India. It has been reported from Denmark, South East Norway and South and Central Sweden (MycoBank, 2020).

9. Peniophora suecica Litsch., Annl. mycol. 39 (2-3): 131, (1941).

Figs. 59-67

Collection examined: India, Himachal Pradesh: Chamba, Bharmour, Manimahesh, Tosh ka got, on fallen angiospermous sticks, Poonam 10486 (PUN).

Remarks: Peniophora suecica is unique in having reddish grey basidiocarps with well developed, light brown subiculum, subfusiform gloeocystidia, conical to subfusiform metuloids and allantoid to suballantoid basidiospores. Dhingra et al. (2014) reported it from district Chamba. This is the second report from the study area.

10.Peniophora violaceolivida (Sommerf.) Massee, Botanical Journal of the Linnean Society 25: 152 (1889).

- Thelephora violaceolivida Sommerf., Supplementum florae lapponicae: 283 (1826).

Figs. 68-75

Basidiocarps resupinate, effused, adnate, up to $200 \mu \mathrm{m}$ thick in section; hymenial surface smooth both in fresh and dry states; grayish orange both in fresh and dry states; margins thinning, paler concolorous. Hyphal system monomitic. Generative hyphae septate, clamped, smooth; light brown, horizontal, up to $4 \mu \mathrm{m}$ wide, less branched, thick-walled in the subicular zone; subhyaline, vertical, up to $2.8 \mu \mathrm{m}$ wide, richly branched, thin-walled in the subhymenial zone. Ancillary elements of 2 kinds: (i) Gloeocystidia subcylindrical, with basal clamp, 46-57 $\times$ 5.5-6.7 $\mu \mathrm{m}$, thin-walled, oily contents positive to sulphovanillin; projecting up to $15 \mu \mathrm{m}$ out of the hymenium (ii) Metuloids conical to subfusiform, with basal clamp, 48$60 \times 6.7-11 \mu \mathrm{m}$, thick-walled, heavily encrusted; projecting up to $10 \mu \mathrm{m}$ out of the hymenium. Basidia clavate, somewhat sinuous, sometime with adventitious septa, 24$49 \times 6.1-7.2 \mu \mathrm{m}$; sterigmata up to $5 \mu \mathrm{m}$ long. Basidiospores $8-9.6 \times 2.8-3.3 \mu \mathrm{m}$, allantoid to suballantoid to subcylindrical, thin-walled, smooth, acyanophilous, inamyloid.

Collections examined: India, Himachal Pradesh: Chamba, Manimahesh, Tosh ka got, on sticks of Juglans regia, Poonam 9180 (PUN), September 04, 2016; Manimahesh, Tosh ka got, on sticks of J. regia, Poonam 10483 (PUN), September 04, 2016; Manimahesh, Tosh ka got, on sticks of J. regia, Poonam 10484 (PUN), September 04, 2016.

Remarks: $P$. violaceolivida is being described for the first time from the state of Himachal Pradesh. It was earlier reported from
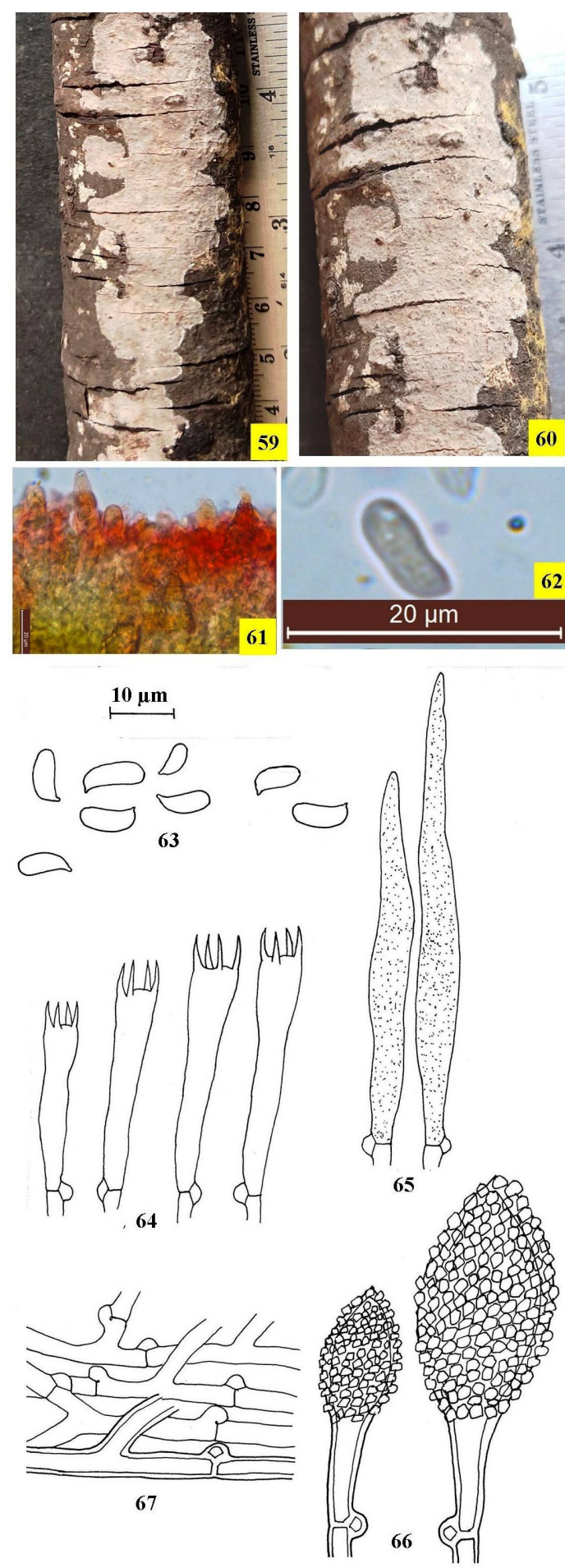

Figs. 59-67. Peniophora suecica: 59-60. Sporophore showing hymenial surface (59. Fresh, 60. Dry); 61-62 Photomicrographs showing 61. V.S. of sporophore showing gloeocystidia and metuloids, 62. Basidiospore; 63-64. Line diagrams showing 63. Basidiospores; 64. Basidia, 65. Gloeocystidia, 66. Metuloids; 67.Generative hyphae.

India by Rehill and Bakshi (1965) from different Indian localities except Himachal Pradesh. The present specimens 


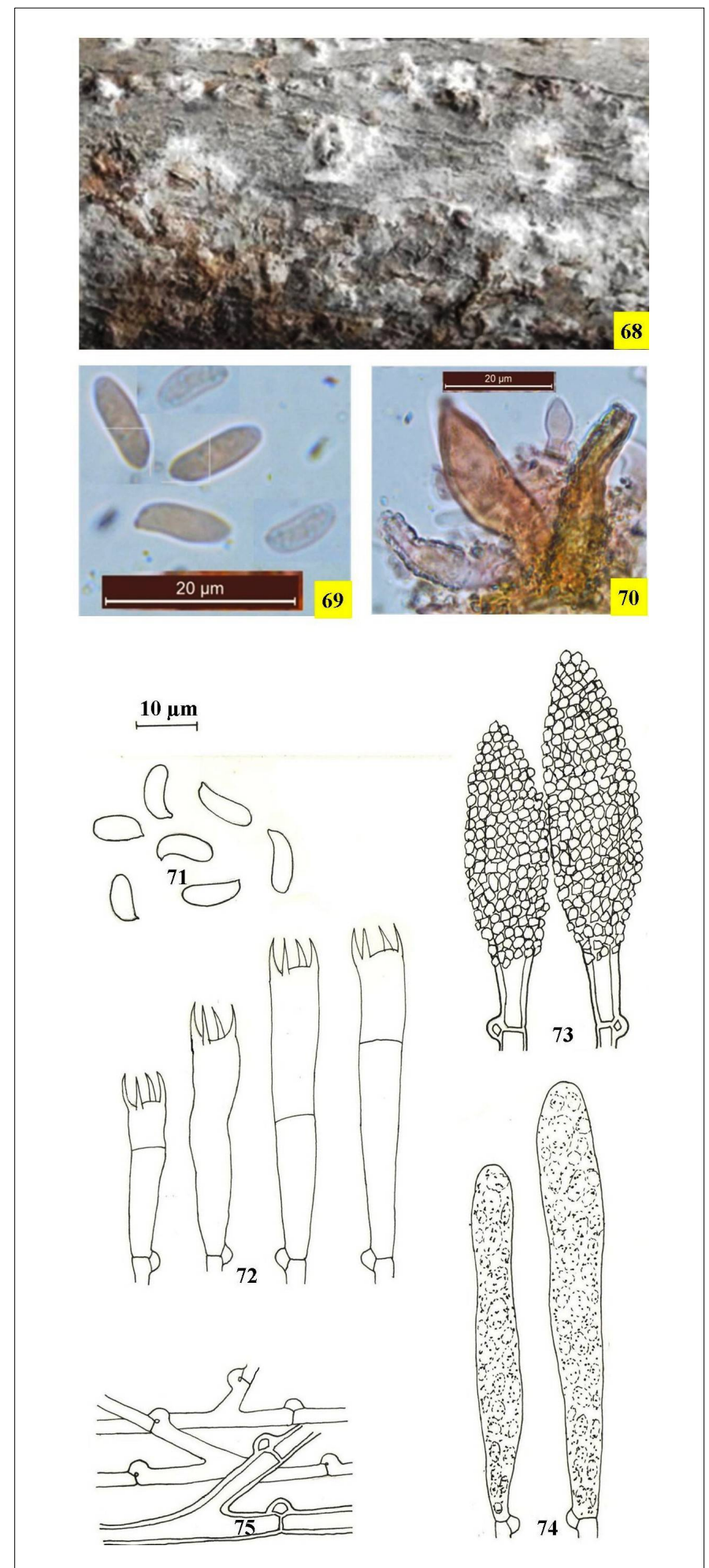

Figs. 68-75. Peniophora violaceolivida: 68 . Sporophore showing hymenial surface; 69-70. Photomicrographs showing 69. Basidiospores, 70. Metuloids; 71-75. Line diagrams showing 71. Basidiospores, 72. Basidia, 73. Metuloids, 74. Gloeocystidia, 75. Generative hyphae.

have comparatively larger metuloids as reported in case of collections made from Japan by Maekawa, (1994).

\section{ACKNOWLEDGEMENTS}

The authors are grateful to the Head, Department of Botany, Punjabi University, Patiala for providing necessary laboratory facilities, University Grants Commission, New Delhi for financial assistance under DRS-SAP DSA level-I programme and Prof. Nils Hallenberg, Gothenburg for expert comments.

\section{REFERENCES}

Andreasen, M. and Hallenberg, N. 2009. A taxonomic survey of the Peniophoraceae. Synopsis Fungorum 26: 56119.

Bernicchia, A. and Gorjón, S.P. 2010. Corticiaceae s. l. Fungi Europaei 12. Edizioni Candusso. Alassio. Italia. 1008pp.

Bhosle, S.R., Lamrood, P.Y. and Vaidya, J.G. 2005. Diversity of Aphyllophoraceous Fungi from the Western Ghats of Maharashtra. In: The Fungi - Diversity and Conservation in India (Eds.: Dargan, J.S., Atri, N.S. and Dhingra, G.S.) Bishen Singh Mahendra Pal Singh Dehradun. 103-113.

Dhingra, G.S. 1993. Three new records of genus Peniophora Cooke from Eastern Himalaya. Geobios New Reports 12: 101-104.

Dhingra, G.S. and Kaur, N. 2005. Resupinate Aphyllophoraceous fungi of Mussoorie Hills- I. Journal Punjab Academy of Sciences 2: 69-72.

Dhingra, G.S., Priyanka and Kaur, J. 2011. A checklist of resupinate, non-poroid Agaricomycetes fungi from North-East India and Bhutan. Synopsis Fungorum 29: 22-70.

Dhingra, G.S., Singh, A.P., Kaur, J., Priyanka, Kaur, H., Rani, M., Sood, S., Singla, N., Kaur, H., Jain, N., Gupta, S., Kaur, M., Sharma, J., Rajnish and Kaur, G. 2014. A checklist of resupinate, non-poroid Agaricomycetous fungi from Himachal Pradesh, India. Synopsis Fungorum 32: 8-37.

Eriksson, J., Hjortstam, K. and Ryvarden, L. 1981. The Corticiaceae of North Europe. Vol. 5: 889-1047. Fungiflora, Oslo.

Index Fungorum 2020. http:\\indexfungorum.org $\backslash$ names $\backslash$ names.asp. [Accessed: 20/03/2020]

Kornerup A. and Wanscher J.H. 1978. Methuen Handbook of colours, $3^{\text {rd }}$ ed. Methuen and Co., London. 252 pp.

Maekawa, N. 1994. Taxonomic study of Japanese Corticiaceae (Aphyllophoraceae) II. Reports of the Tottori Mycological Institute 32:1-123.

MycoBank. 2020. Fungal databases. Nomenclature and species banks. [Accessed: 20/03/2020].

Natarajan, K., and Kolandavelu, K. 1998. Resupinate Aphyllophorales of Tamil Nadu, India. Centre for Advanced Study in Botany, University of Madras. $131 p p$. 
Poonam, Singh, A.P. and Dhingra, G.S. 2017. Corticioid fungi new to district Chamba (Himachal Pradesh). Kavaka 49: 77-81.

Prasher, I.B. and Ashok, D. 2013. AChecklist of Wood rotting Fungi (non-gilled Agaricomycotina) of Himachal Pradesh. Journal on New Biological Reports 2 (2): 71-98.

Prasher, I.B. and Lalita. 2013. A Checklist of Wood rotting Fungi (non-gilled Agaricomycotina) of Uttarakhand. Journal on New Biological Reports 2 (2):108-123.

Ranadive, K.R. 2013. An overview of Aphyllophorales (wood rotting fungi) from India. Int. J. Curr. Microbiol. App. Sci. 2 (12): 112-139.

Ranadive, K.R., Vaidya, J.G., Jite, P.K., Ranade, V.D., Bhosle, S.R., Rabba, A.S., Hakimi, M., Deshpande,
G.S., Rathod, M.M., Forutan, A., Kaur, M., NaikVaidya, C.D., Bapat, G.S. and Lamrood, P. 2011. Checklist of Aphyllophorales from the Western Ghats of Maharashtra State, India. Mycosphere 2: 91-114.

Rattan, S.S. 1977. The resupinate Aphyllophorales of the North Western Himalayas. Bibliotheca Mycologica 60, Cramer, Germany. 427pp.

Rehill, P.S. and Bakshi, B.K. 1965. Studies on Indian Thelephoraceae II. Indian species of Peniophora \& Corticium. Indian For. Bull. 242: 1-30.

Samita and Dhingra, G.S. 2013. Peniophora hallenbergii sp. nov. from India. Mycotaxon 126: 235-237.

Sharma, J.R. 2012. Aphyllophorales of Himalaya. Botanical Survey of India, Ministry of Environment and Forests, Kolkata. 590pp. 